\title{
"I experienced freedom within the frame of my own narrative": The contribution of psychodrama techniques to experiential learning in teacher training
}

\author{
Ina ter Avest ${ }^{1,2}$
}

Published online: 30 January 2017

(C) The Author(s) 2017. This article is published with open access at Springerlink.com

\begin{abstract}
To prepare Dutch students in education for critical situations in their professional life as a teacher, part of their training is to ask them to reflect upon their own experiences in their life as a child, a pupil and a student - experiences of crucial moments or with significant others which are still of the utmost importance to them. This article underlines the significance of so-called "experiential learning" in student career counselling. In this context, experiential learning is understood as an extension of in-depth reflection on critical incidents and critical persons in the biography of pre-service teachers. This reflection - customary and effective in Dutch teacher training - is a verbal process. However, this technique does not seem to be adequate for many students from other cultural backgrounds (e.g. secondgeneration descendants of migrant workers). By consequence, some of these students are not able to take newly offered information on board, but remain imprisoned in their own culture-related narrative, their own ethnic society of mind. Research has shown that for these students, psychodrama techniques, focusing on non-verbal and playful aspects of reflection, seem to be more suitable. The author of this article presents a sample case from a pilot study which used one of the psychodrama techniques called the empty chair. The findings of the pilot study are promising in the sense that experiencing different I-positions does seem to help students from other cultural backgrounds to develop agency in responding to hitherto unfamiliar and confusing situations.
\end{abstract}

Keywords Multi-voiced self · Psychodrama - Agency · Student career counselling · Professional development $\cdot$ Teacher training

Ina ter Avest

k.h.ter.avest@vu.nl; i.teravest@inholland.nl

1 Inholland University of Applied Sciences, Amstelveen, The Netherlands

2 Vrije Universiteit (VU University), Amsterdam, The Netherlands 
Résumé «Je me suis libéré/e à travers mon propre récit »: contribution des techniques du psychodrame à l'apprentissage expérientiel dans la formation des enseignants - En vue de préparer les étudiants néerlandais aux situations critiques de leur future vie professionnelle d'enseignant, la formation prévoit une analyse personnelle de leurs propres expériences en tant qu'enfant, élève et étudiant - les vécus de moments décisifs ou avec des êtres chers qui revêtent encore pour eux une grande importance. L'article souligne l'intérêt dans l'orientation professionnelle des étudiants de ce que l'on appelle « l'apprentissage expérientiel ». Il signifie dans ce contexte une extension de la réflexion approfondie sur les incidents décisifs et sur les personnes déterminantes dans la biographie de ces enseignants en formation. Cette réflexion, qui est courante et efficace dans la formation des enseignants aux Pays-Bas, consiste en une démarche orale. Cette technique ne semble cependant pas adéquate aux nombreux étudiants issus d'autres contextes culturels (par exemple les descendants de seconde génération des travailleurs immigrés). Certains de ces étudiants ne peuvent donc tenir compte de l'information nouvellement proposée, et restent enfermés dans leur parcours rattaché à leur culture, à leur communauté ethnique de pensée. Les études de recherche constatent que pour ces étudiants, les techniques du psychodrame axées sur les aspects non verbaux et ludiques de la réflexion semblent plus adaptées. L'auteure de l'article présente un cas type tiré d'une étude pilote qui a appliqué une technique du psychodrame appelée la chaise vide. Les résultats de cette étude sont prometteurs en ce sens que le vécu de différentes positions $d u$ Je semble aider les étudiants issus d'autres contextes culturels à développer une agentivité, en réagissant à des situations jusqu'alors inhabituelles et perturbantes.

\section{Introduction}

Students training to be teachers need to be prepared for a wide range of future situations with pupils and their parents. Therefore, it is part of Dutch teacher training to invite students to reflect on their own pivotal experiences which they made as a child, pupil or student, or which influenced their career choice. Such experiences might include living through crucial moments or interactions with significant others which are still of the utmost importance to their (future) career as a teacher. This article focuses on the importance of so-called experiential learning in student career counselling (SCC). Experiential learning is understood as an extension of in-depth reflection (Kelchtermans and Hamilton 2004; Kelchtermans 2006) on critical incidents and critical persons in the biography of students aspiring to become teachers.

In-depth reflection is a complex process of emotional involvement in and commitment to a situation, while at the same time urging distance, and accordingly requiring analytical skills. Most of the time in SCC, reflection is a verbal process. In a reflection session, coached by the teacher trainer/lecturer, a small group of students focuses on a "case", a so-called critical incident perceived during a practical period by one of the students. They discuss the ins and outs of the 
situation, its possible causes and the more or less expected consequences, according to what is known in Dutch as the zevensprong [originally: a seven-step folk dance]. This problem-oriented learning method shows similarities with Moreel Beraad [moral case deliberation] (see Molenwijk et al. 2011; Ter Meulen 2016), considering the ethics of a solution by going through a process of seven successive steps:

Step 1: Introduction of the case by the person who is putting the problem on the table, and definition of a dilemma; "Should I ... or should I not ...?" related to the core value(s) at stake;

Step 2: Questions for clarification by the group members (e.g. what is the age of the person(s) involved in the case; what is the context of the case; etc.);

Step 3: In the group: Making of a systematic inventory of the values - and, by consequence, the norms - at stake for the different persons involved - from their perspective;

Step 4: In a group discussion: Elaboration on the pros and cons of the consequences in case "I do ..." and in case "I do not ...";

Step 5: Each member of the group individually makes her/his choice for the best possible solution, according to her-/himself;

Step 6: In a group discussion: Comparison of the different choices made, resulting in a group decision on opting for either "I do ..." or "I do not ..."; and

Step 7: In a group discussion: Planning of actions to minimise the "pain" which results from "I do not ...".

The zevensprong challenges group members to discuss the situation within which the critical incident occurred from different perspectives, such as the perspective of the teacher, the pupil concerned, classmates and possibly the parents. In the end, a comparison is made between how the student who brought the case into the discussion actually handled the unfamiliar and confusing situation, and the possible solutions arrived at by the group. Last but not least, lessons learned are brought to the table by each of the participants of the zevensprong.

Next, different voices and their different positions as they might possibly be present in the students' society of mind $^{1}$ are focused upon (Hermans and Gieser 2012; Hermans and Hermans-Jansen 1995). In so doing, the students are expected to arrive at a better insight into the situation and into themselves, not as passive factors but as active actors in that situation.

However, research has found that, most of the time, the newly acquired knowledge and gained insight does not in fact appear to be integrated into students' actual behaviour as novice teachers in the classroom (Ter Avest 2014a).

One other factor which is decisive to students' sense of identity is culture. I am referring here to students who are members of minority groups in the Netherlands,

\footnotetext{
1 The society of mind, as used in dialogical self theory (DST), refers to "the observation that many of the social processes, like dialogue and fights for dominance, that can be observed in society at large also take place within the self as a "society of mind" (Hermans and Hermans-Konopka 2010, p. 1).
} 
which includes more recent migrants such as refugees, but also so-called "secondgeneration" descendants of migrant workers who came to the Netherlands in the 1960s and 1970s. For these students, to arrive at an integration of academically acquired insights into their actual situation as members of minority groups in the Netherlands, the verbal process of reflection - familiar to Dutch teacher training seems to be inadequate for their deeper understanding of the "case". By consequence, this way of reflection does not pave the way for these students taking on board the information acquired during the sessions with their peers and the lecturer.

Sometimes, according to the lecturers, students remain imprisoned in their own culture-related narrative, their own ethnic society of mind (Hermans 2006). In their discussion on culturally appropriate pedagogy, Phuong-Mai Nguyen et al. point to the need for harmony in "we"-cultures, ${ }^{2}$ where "learners suppress their personal desires, avoid conflicts and hence avoid criticising their peers or claiming any authority" (Nguyen et al. 2006, p. 7). Lecturers are in urgent need of a more pervasive and culturally appropriate way of reflection, resulting in students' deeper understanding of themselves as actors in critical situations (Janssens 2010). Psychodrama techniques focus on re-presentation of and re-enacting so-called critical incidents (Kelchtermans 1994) in non-verbal and playful ways, and as such contributing to in-depth reflection (Kelchtermans 2006). Psychodrama and its specific playful and non-verbal techniques seem to answer lecturers' needs for deep reflection and at the same time to be more suitable for students with different cultural backgrounds and different levels of Dutch language proficiency as well as partly related to their cultural background - a different level of development in their verbal expression of experiential knowledge. From the Dutch psychologist Jutta König, referring to "a number of cases [involving career coaches and refugees] in which subtle discourses [were] analysed in an action research approach" (König 2012, p. 275), we learn that

On the one hand, fear and uncomfortable emotions enhanced the tendency to withdraw from complexity in career coaches at the outset of their coaching trajectories and on the other hand, cultural hybrids hide their cultural diversity due to the dominant discourse in society (ibid.).

In this contribution to a special issue on experiential learning, I first describe the dialogical self theory with its core concepts of dialogue and society of mind. Next, I present psychodrama and focus on one of its techniques, the so-called empty chair method. The third section is dedicated to the case study of "Rafaëla" and her experiences with the empty chair. I end with a discussion, conclusion and some recommendations for future applications of psychodrama techniques in experiential learning.

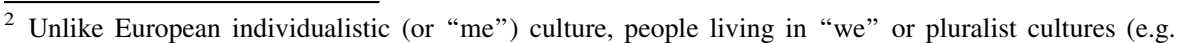
many Asian countries) avoid standing out as individuals at all costs and strive to fit in with the community or society as a whole.
} 


\section{Dialogical self theory}

According to Alvin Goldman's overview of the Theory of Mind (ToM), the family of ToM-conceptions refer to the "cognitive capacity to attribute mental states to self and others" (Goldman 2012, p. 2). Goldman distinguishes between a third-person approach, a third-person/first-person contrast and self-attribution. Dialogical Self Theory (DST) is part of the self-attribution family, claiming privileged access to a person's own mental state. DST focuses on verbal expressions of these mental states of the person her/himself and her/his perceptions of physical changes due to emotional feelings accompanying strongly held convictions.

Through the lens of DST, a person is seen as a motivated storyteller (Hermans and Hermans-Jansen 1995). Critical incidents and critical persons play their role in the biographical narrative, positioning themselves as inner voices, so-called Ipositions in the space of a multi-voiced self, the society of mind (Hermans and Gieser 2012). In telling and retelling one's narrative, choices are made about the sequence of situations, and relevant voices are allocated different positions. The narrator is thus making choices between more or less significant others who play a role in the narrative and also chooses which aspects are sufficiently relevant be included in the story. So, in the self-narrative, different so-called voices are heard for example, the voice of the family of origin and its way of enculturing children into a particular tradition (Gregg and Gary 2013); the voice of a teacher who praised you for doing your homework and not only saw you as a student but noticed you as a person (Vandamme 2014); and possibly the voice of a religious community you were raised in (Pitstra 2013; Zittoun 2013). In a self-narrative, a story situated in a lifetime, the voice of a teacher might come more to the fore in a certain situation, and the voice of a classmate might be silenced at that very moment. One might say that the self-narrative is the result of an interesting process of voicing and listening; an intriguing dialogue between different voices, placed in a certain hierarchy in different I-positions, more or less dominant or more or less opposing each other - at the end of the day constituting identity and, in our case, constituting a normative professional identity.

The self, the society of mind in DST, is represented as a space consisting of two concentric circles (see also Verhofstadt-Denève 1995). The inner circle represents internal positions which feel as if they are really "me", for example "me as a mother" or "me as an ambitious student". The positions in this inner circle can be either personal positions or social positions. Personal positions are, for example, "reluctant me", "Dutch-Moroccan me", "ambitious me", and "helpless me"; social positions are, for example, "sportsman/sportswoman me", "student me" and "part-time supermarket employee me". In the outer circle, positions are represented which concern feeling part of "my environment", such as "my friends", "my university" and "my colleagues" as I perceive them, the perception of them becoming a part of the multi-voiced self (see also Verhofstadt-Denève 2012).

To facilitate a dialogue between different voices and to integrate a dominant voice, a possible rigid I-position in one's multi-voiced self, a person's active involvement, is needed. To consider this active involvement, the competency of 
agency, the concept of identity capital as described by the Dutch social-psychologist Mick Matthys is useful. In his PhD thesis Doorzetters [Go Getters] (Matthys 2010), Matthys follows the psychologist James Côté in his definition of the concept of identity capital as a diversified portfolio of psychological competencies enabling an individual to act in a strategic way and as such be the director of their own life, making use of context-related skills, role perceptions and qualities (Côté 1996; Matthys 2010, p. 96). The concept of identity capital is closely related to the concept of agency (Matthys 2010, p. 97), and to metacognition (Gonçalvez and Ribeiro 2012).

An important task in the process of (normative professional) identity development is to learn to respond to different role expectations in different contexts and to cope with the tension(s) which may arise from different value orientations and a different hierarchy of the different positions. Values and skills in one context (for example, the context of a migrant family) may be appreciated less or not at all in another context (for example, the university context in the Netherlands). On the other hand, the transformation of a value or skill appreciated in one context can also facilitate successful self-presentation in another context. In order to handle competencies in a flexible and adequate way, it is very important to properly perceive, receive and interpret the situation a person is in; it is a matter of flexible role taking and role changing (Kortram 2004; Selan 1980; Sundén 1966). Some people feel forced to choose between different roles and forget what they have learnt in one context (Matthys 2010, p. 334); others show themselves able to reflect upon their roles in different contexts and play the game of playful identities, aware of the power of their competency to use their strengths and flexibly adapt to different situations (Matthys, 2010, p. 333). Matthys elaborates on the definition of Côté by articulating the dynamics of identity capital. Matthys adds to Côtés description that identity capital is a "potential" to be elaborated upon in a process of reflection regarding commitment to a variety of situated identities, or I-positions, and their relationships with cultural and social capital, as well as allowing for distancing in relation to the above-mentioned capitals, resulting in the dynamics of a playful identity. This process can be clarified with the metaphor of playing marbles: knowing the basic rules and the structure of the game enables a child to add to a perceived lack of marbles at the start of the game (his/her social and cultural capital) (Matthys 2010, p. 369) and stimulates the inclusion of a variety of other childrens' marbles (that is, the integration of different sub-cultures). It's all about "the game and the marbles" - even with a small number of marbles at the start, it is possible to play the game successfully.

\section{The self confrontation method}

As a method of in-depth reflection, or, according to Charles Taylor, radical reflexion (Taylor 1991) Hermans and Hermans-Jansen (1995) developed the self confrontation method (SCM). SCM stimulates the exploration of different voices which are positioned in the self and valued in different ways. Attentive listening to these voices contributes to creating an awareness of the situation and a hierarchy of the position of different voices, so-called I-positions. For example, in her family 
life, the voice of student Rafaëla's (see below) mother is dominant and urges her to be obedient and respond to duties according to her position in the family. In the specific context of her home, the voice of "my mother" is valued higher than the voice of "my friends", whose voices might almost be silenced. Yet, when going shopping with her friends, the collective voice of "my friends" comes to the fore and their approval or disapproval is valued highly, while in that specific situation the voice of "my mother" moves to the background (although it is never completely silenced). When at a certain moment student Rafaëla receives a text message on her mobile phone from her mother to come home to assist in family affairs, the voice of "my mother" changes position, as does the collective voice of "my friends".

Intrapersonal and interpersonal dialogues are interwoven; the collective voice of "my friends", as it is heard in real-life conversations, can play a dominant role in an intrapersonal dialogue when standing in front of the mirror and deciding what to wear to a party.

For each person, it is a challenge to become both an agent and the director of the choir of inner voices. The self confrontation method is a means to start a conversation between the inner voices, coached by a facilitator, to construct a space and create a hierarchy of the voices in their so-called I-positions - representing the dominance or sub-dominance of critical situations and significant persons in the past, the present and probably also in the future. SCM is a dialogical method aiming at self-insight and discovering a way, or maybe changing the actual way, to become an active agent in the society of mind.

Coined as identity capital by Matthys (2010), Matthys' starting point for becoming an agent is that every person has in some way a certain strength to recognise their inner I-positions and - depending on the context a person is situated in - to voice them, listen to them or silence them as necessary. Adding this concept of identity capital to Hermans' concept of DST, it becomes possible to identify the inner strength and (hidden) competencies which feed the "author" of one's own biography, aware of the need of autonomy as well as togetherness in professional and private life.

The development and amplification of identity capital is central to Leni Verhofstadt-Denève's model of developmental psychotherapy, and is denoted in what is termed Verhofstadt's wheel (De Laat 2005, p. 40ff. Verhofstadt-Denève 1995 , p. 65ff.). In dialogical conversations with her clients, Verhofstadt stimulates reflection with regard to the positions of a variety of voices, enriching Hermans' approach by adding reflection upon a desired ideal situation, including the ideas a person has about "me, the best person in the world", and ideas about significant others as she or he would love the others to be. Verhofstadt's approach uses six fundamental questions, ${ }^{3}$ and the way a person responds to these questions gives insight into the degree of rigidity or flexibility with regard to further (professional) identity development. Although Verhofstadt's approach is verbal, she did add a playful element to the method she and her colleagues developed for children (Dillen

\footnotetext{
3 The six questions are: (1) Who am I? [self-image]; (2) Who would I like to be and become? [ideal-self]; (3) What are the others like? [alter-image]; (4) What should the others be like? [ideal-alter]; (5) How do the others perceive me? [meta-self]; and (6) How should the others perceive me? [ideal meta-self] (Verhofstadt-Denève 1995, p. 78).
} 
et al. 2009). It is this playful element which I see as the core aspect of psychodrama methods, in conjunction with the above-mentioned verbal instruments stimulating reflection. I will return to that later, after I have positioned our students in their phase of (professional) identity development.

\section{Identity development}

Students embarking on their studies in the field of education are generally in a phase of their identity development known as early adolescence (Breeuwsma 1993, p. 227ff.), between puberty and adolescence. In addition to physical growth in terms of height, changes in body shape relating to gender maturation, and a growing awareness of sexual identity, an important aspect of the phase of early adolescence is the change in relationships and position of the voices of the family and of peers, classmates and colleagues (Selan 1980). This is a matter of loosening bonding relationships and building up commitments with new significant others (Matthys 2010; Putnam 2001). To tackle this period of change, an attitude of curiosity and exploration is needed. According to Canadian developmental psychologist James Marcia, identity develops and is constituted between activities of exploration and the subsequent development of sustainable commitments. Among the areas young adolescents have to explore are, for example, the field of intimate relationships, political commitments and the field of professional life (Marcia 1980). Marcia distinguishes four stages young people go through as they explore these fields and develop their commitments: (1) foreclosure; (2) identity diffusion; (3) moratorium and (4) identity achievement. ${ }^{4}$

Identity development takes place in the context of family life, as well as in the public domain (of which the university is a part), in the peer group, and in the future world of the profession the student is educated and trained for at university and in practical periods. In these contexts, we find a variety of cultures and sub-cultures of which a person is a member - by birth (in the family) or by choice - either after a phase of exploration, like a sports club, or not: these are the so-called membership groups. For some young adolescents, belonging to a group by birth is very important - for example, for the students with an Islamic Moroccan or Turkish migration background (De Jong 2012). As a result, the comfortable and safe contexts of the family and the mosque play a decisive role in the lives of second- and thirdgeneration Moroccan-Dutch and Turkish-Dutch students (see Okafor and Honey 1998). Family and mosque are essential in the lives of these students, just like recognition and esteem by others are important (see also Hermans and HermansJansen 1995). In their identity development, in their multi-voiced self, alternate different voices are dominant according to their own perception and self-valuation, or are given a dominant voice by appointment of others (Kortram 2004). The dominance of a cultural (e.g. Dutch), historical (e.g. Second World War) or

\footnotetext{
4 The four stages encompass: (1) foreclosure: blind acceptance of whatever ideology or value system their parents or family members have taught them; (2) identity diffusion: a struggle of indecisiveness which stands in the way of making progress; (3) moratorium: experimenting rather than making commitments to an ideology or a career; and (4) identity achievement: reaching decisions in terms of committing to ideologies and embarking on a carefully chosen career path.
} 
religious (e.g. Islamic) voice may be at the base of a rigid self-narrative, excluding new experiences and knowledge. This kind of rigid self-narrative features similarities with the status of foreclosure, as described by Marcia (see above).

\section{Psychodrama}

Psychodrama, according to Marijke Arendsen Hein, is about "imagining and playing situations, memories, fantasies and dreams of a person's biography, instead of talking about these things" (Arendsen Hein 2004, p. 11). Psychodrama is about living through and experiencing anew either suppressed or not suppressed aspects of the life span, without comment or discussion. The purpose, according to Jacob Moreno, the founding father of psychodrama, is "gaining insight by acting" (quoted in Arendsen Hein 2004, p. 11). Many techniques have been developed and recognised as specific psychodrama techniques, including storytelling, voice dialogue, mirroring, social atom and the empty chair (Gilhuis et al. 2014). ${ }^{5}$ Results of research on the effects of psychodrama are promising, especially with regard to dysfunctional anxiety and precipitous mood swings and/or changes in attitude. In particular, it is through the technique of doubling (playing two roles in the same scene) and change of position that individuals not only manage to gain insight into their own behaviour and motivations, but find they can also make a start on changing their attitudes (Gilhuis 2014).

Below, I present the case of Rafaëla, ${ }^{6}$ a student who experienced feelings of anxiety related to her ambitions regarding her planned career choice. The advantage of a case study is its "avoidance of diagnostic categories and labels" and its "concern with what a person does, thinks and feels" (Maddux 2005, p. 22). In this way, justice can be done to the "richness of the empirical reality" by using the respondent's own language as much as possible (Swanborn 1994, p. 158). Considering Rafaëla's case, I concentrate on radical reflexivity ${ }^{7}$ as experiential knowledge, and pay close attention to "the thick of what is going on" (Stake 2005, p. 449). In doing so, I aim to parallel the reader's "actual experience feeding into the most fundamental processes of awareness and understanding", thereby facilitating knowledge transfer, that is, enabling "people to make some generalizations entirely from personal or vicarious experience" (ibid., p. 455). In my view, using the empty chair in teacher training offers a promising example of communicative generalisability and case-to-case transfer (Smaling 2009) and is an applicable and useful technique for gaining an insight into these kinds of student's anxieties.

\footnotetext{
5 The mirroring technique allows the person to look at their own behaviour, facial expression, their way of speaking, as this is represented (mirrored) by an other person - as if the person sees her-/him self in a mirror. The "stand-in" imitates the person concerned (De Laat 2005, p. 143). The social atom technique invites the person to represent her/his own network by way of several empty chairs. To enliven the social atom, the chairs are decorated with colourful shawls and other objects articulating a particular characteristic of each person represented (De Laat 2005, p. 169). The empty chair technique is demonstrated in the case study of Rafaëla later on in this paper.

6 This is a pseudonym to protect the identity of the student.

7 Radical reflexivity enables one to step outside of oneself in order to reflect upon the roots, the basis of one's own reasoning and desires. The adjective "radical" refers to the original meaning of the Latin word radix [roots].
} 


\section{The empty chair}

In the empty chair technique, students are invited to take the position of "the other" in the way "the other" has a position in their own society of mind (VerhofstadtDenève 1995), not only by thinking of the other, or by role-playing the other, but in addition to that by literally sitting in the chair of the other - occupying the other's position physically as if this were a real-life person. In this way, the student's qualities are challenged to empathise with the other inside her or himself. This may result in a conflictual experience in the student's society of mind, and, as such, stimulate reflection and thinking, or an internal dialogue (Arendt 1978, 2013). The empty chair is a method often used to explore critical situations, or to examine the plot of a self-narrative in more detail. The method of the empty chair, in my view, is one of the many ways which enables experiential learning and thus contributes to the normative professional development of students living in two cultures, be it the Dutch and the migrant culture or the middle-class Dutch and the working class culture. As part of a pilot study on facilitating and hindering aspects in career development, $\mathrm{we}^{8}$ invited students to talk about their life, first sequencing their biography into "chapters" from baby and childhood to today's student life, and then focusing on a particular critical situation to be explored using the empty chair technique. In the following case study, the student's active participation in the empty chair adds to her cognitive knowledge an experiential knowledge of what it means to be a multi-voiced self with different voices in different positions in the society of mind.

\section{The case of Rafaëla}

We, the facilitator, one other member of the research group and six students are seated in a circle in one of the classrooms of our Teacher Training Institute.

There are two chairs in the centre of the room: one is for Rafaëla, an ambitious student who wishes to finish her teacher training, and the other is for "the indecisive Rafaëla", doubting whether she ever will be able to start her profession as a teacher.

Rafaëla positions herself on one of the chairs, saying:

"I am 'the indecisive Rafaëla'. Very often I have to ask for help - for example, when I don't understand the lecturer in workshops. In my family, there are two younger brothers. My younger brother, Mehmet, started to do business with the world of crime; my mother's wish is that my father never will know about this. I translate letters from the Ministry of Legal Affairs for my mother. My mother says: 'If your father ever gets to know about Mehmet's practices, he will never ever name him 'my son' any more.' I should study many hours a day, but ... the situation in my family keeps me busy. I don't know what to do ... I am afraid, so afraid that I will never be the teacher I wish to be!"

\footnotetext{
8 "We" refers to the research group of which I was the leader at the time of the research.
} 
The facilitator in this dialogical conversation (shared inquiry) then invites Rafaëla to sit down on her own chair, and respond to the story of her indecisive self. Rafaëla thinks aloud:

"To tell the truth, I would like to tell my 'indecisive self': 'You know, little girl, this all is going on for too long a time; take care of yourself and focus on your study; take care that you pass your exams; it's all about your future as a professional teacher! Don't allow yourself to be tormented by your family!'

Instead of this, she asks her indecisive self:

"What would you like to tell your father, your mother and Mehmet?"

The facilitator then asks Rafaëla to position herself back on the chair of her indecisive self and respond to Rafaëla's questions.

"To be honest, I'd rather tell my mum: 'It's your problem that you don't want dad to be involved. Mind your own business!' And regarding my little brother Mehmet: 'I am willing to help you, but you have your own part in changing your life!"' The 'indecisive Rafaëla' immediately adds to this: "Of course, I never dare say a thing like that. Such a way of doing does not fit our culture of respect for parents. Imagine what my father will do when I tell him the truth about Mehmet. I hide myself behind my university homework, but at my desk there's nothing else but racking my brains ..."

Back on her own chair, the facilitator invites Rafaëla to respond to the indecisive Rafaëla. Rafaëla's reaction is full of empathy:

"I really do understand that for you this is an unruly situation, but dear 'indecisive self', what is the worst thing that may happen when you raise your voice?"

This is an inconvenient question for the indecisive Rafaëla, reflected in her answer,

"I really am afraid that my father will tell Mehmet that he is not his son any more, and I cannot live in a broken family. I really don't know what to do.”

From her own chair, Rafaëla answers this deafening appeal for help from her indecisive self:

"Would it be possible to ask your father for help, and include him in the family affairs with his expertise as an older person? In that way you would give him the respect that fits his position as a father. Could you, for example, say something like: 'Father, I have to tell you something about Mehmet: it's not a pleasant thing to tell, but we badly need you to make things work for Mehmet again.' Would that be possible?"

We notice the doubt on the face of Rafaëla's indecisive self. The indecisive self is scared to trample a core value of Islam - that is, respect for parents. However, the willpower of Rafaëla's ambitious self who wants to finish her teacher training is very strong and coming to the fore at this moment. This ambitious self knows how 
to ask for help, because she did it many times during her study - for example, asking for help from classmates when she did not completely grasp the essence of a workshop.

Putting herself in the position of the indecisive self, she approaches the ambitious self with the question:

"Please come to the fore when I meet my father, and help me to have this difficult conversation in a respectful way".

Back on her own chair, Rafaëla states in a self-confident way:

"Let's take the challenge! I feel the strength of my 'ambitious self' with whom I can stand this situation!"

\section{Discussion, conclusion and recommendations for future research}

The case study depicts the troublesome situation of Rafaëla. Detailed consideration is given to the development of one person: the student Rafaëla. Her narrative, however, is exemplary in that it reflects the feelings of many other current students, in particular students from migrant backgrounds. They struggle with paradoxical academic cognitions conflicting with experiential knowledge, and conflicting feelings which go together with the dilemmas these students have to respond to in their actual behaviour (Ter Avest 2014b). Rafaëla's case is thus representative of the situation which many of her peers are also finding themselves in. In psychodrama, Rafaëla is given time and space to do the necessary groundwork of exploring the pros and cons in her dilemma. She is an example, not because of her specific insights and her decision to go and meet her father, but because of her willingness to enter into a process of change. While Rafaëla should not be taken as a model in her personal solution for the situation, what is representative for the effect of the application of the psychodrama technique to her dilemma is the courage she shows in doubting her behaviour until now. She has been enabled to enter into a reflective process with an open end, and has learned a technique which she can use - in the long term - to meet and tackle future challenges.

Experiential learning is not learning from just one experience; however intensive this experience may be. Time, much time, is needed to change the position of a voice - not only just for the moment, but in a more sustainable way: time to leave the "prison", which in some sense gave a comfortable position to the respective voices, or at least in Rafaëla's case, a position she was used to; time to trust her own strengths, to experience how it feels when voices are heard from different - more or less dominant - positions. Let us keep in mind that "practice makes perfect". Should we meet Rafaëla after a few years as a professional teacher, maybe her indecisive self will be almost silenced by that time, or at least have made room for the self-confident self; or maybe the ambitious self in dialogue with the respectful self has developed into a respectful problem-solving self - this latter voice Rafaëla uses to discuss family affairs with her father and invite him in a loving and respectful way to be a partner in the process of problem solving. Inspired by her 
experience with the empty chair, Rafaëla has learned to bring voices to the fore or to silence them according to the situation. She embraces the playful flexibility of her society of mind. We can expect her to further develop differently positioned voices in her multi-voiced self - the multi-voiced self of a self-confident Muslim young woman in the multicultural context of the Netherlands.

The empty chair in our pilot study demonstrates its strengths in the situation of students in their adolescence, exploring and listening to the choir of their multivoiced self, a self on its way from puberty to (young) adolescence. The technique shows the experience of what it feels like to bridge the gap - all of a sudden, and in an unexpected and intensive way - between old and in some way comfortable commitments, and new commitments, to which this experience may give way. Students in this pilot study experienced in a playful manner what it means to be liberated from a dominating voice in their own narrative, their own society of mind, and to arrive at a new voice, thereby adding to their coping strategies. Although the physical activity of changing chairs is helpful for some students in developing flexibility in their society of mind, not all students will feel free in the context of a classroom and amidst their classmates to open themselves up to unexpected questions and to confront new insights. Lecturers, in their role as facilitators, should be trained in group dynamics and be made fully aware of the (im)possibilities of the empty chair with some of their students.

In the example above, we have heard different voices related to one student's migrant background, while less attention is given to the voice of the facilitator of the empty chair. Keeping in mind Jutta König's remark, cited earlier in this article that "fear and uncomfortable emotions enhanced the tendency to withdraw from complexity in career coaches at the outset of their coaching trajectories ..." (König 2012, p. 275), the training of teacher trainers/lecturers to become facilitators of a culturally appropriate empty chair is of pivotal importance for the success of this intervention.

To make experiential learning even more effective for students, more research is needed into how the empty chair and other psychodrama techniques can be helpful in the development of the normative professionalism of students and novice teachers from all kinds of different and sometimes troublesome backgrounds and related different and maybe conflicting value orientations. Last but not least, further research is also needed in terms of listening to gendered voices and understanding the basic experience of ourselves - as lecturers, being different - in order to enable our students to experience freedom within the frame of their narrative.

Open Access This article is distributed under the terms of the Creative Commons Attribution 4.0 International License (http://creativecommons.org/licenses/by/4.0/), which permits unrestricted use, distribution, and reproduction in any medium, provided you give appropriate credit to the original author(s) and the source, provide a link to the Creative Commons license, and indicate if changes were made.

\section{References}

Arendsen Hein, M. (2004). Psychodrama en transactionele analyse. Inzicht door (trans)actie. [Psychodrama and transactional analysis. Insight through (trans) action]. Houten: Bohn Stafleu Van Loghum. 
Arendt, H. (1978). Life of the mind (posthumously published from an unfinished manuscript edited by Mary McCarthy). New York: Harcourt Brace Jovanovich.

Arendt, H. (2013). Denken. Het leven van de geest [Thinking. The life of the mind]. (Translated by D. de Schutter and R.Peeters). Zoetermeer: Uitgeverij Klement.

Breeuwsma, G. (1993). De constructie van de levensloop [The construction of the life cycle]. Amsterdam/ Meppel: Boom/Open Universiteit.

Côté, J. E. (1996). Sociological perspectives on identity formation: The culture-identity link and identity capital. Journal of Adolescence., 19(5), 417-428.

De Jong, M. (2012). Ik ben die Marokkaan niet. Onderzoek naar identiteits-vorming van MarokkaansNederlandse HBO-studenten [I am not that type of Moroccan guy. A study on identity construction of Moroccan-Dutch university students]. Amsterdam: VU University Press.

De Laat, P. (2005). Psychodrama. Een actiegerichte method voor exploratie, reflective en gedragsverandering [Psychodrama. An action-oriented method for exploration, reflection and change of behaviour]. Assen: Koninklijke Van Gorcum.

Dillen, L. M., Siongers, D. Helskens, \& Verhofstadt-Denève, L. (2009). When puppets speak: Dialectical psychodrama within developmental child psychotherapy. Journal of Constructivist Psychology., $22(1), 55-82$.

Gilhuis, H. (2014). Onderzoek: effectiviteit en werkzame factoren [Research: effective and active factors. In H. Gilhuis, P. de Laat, \& F. van Hest (Eds). (2014). Psychodrama in praktijk: Therapie op de vloer [Psychodrama in practice: Therapy on the floor] (pp. 299-314). Amsterdam: Hogrefe Uitgevers.

Gilhuis, H., de Laat, P., \& van Hest, F. (Eds.). (2014). Psychodrama in praktijk: Therapie op de vloer [Ppsychodrama's practice. Therapy on the floor]. Amsterdam: Hogrefe Uitgevers.

Goldman, A. I. (2012). Theory of mind. In E. Margolis, R. Samuels, \& S. Stich (Eds.), Oxford handbook of philosophy and cognitive science. Oxford handbook series (pp. 402-424). Oxford: Oxford University Press.

Gonçalvez, M. M., \& Ribeiro, P. (2012). Narrative processes of innovation and stability within the dialogical self. In H. J. M. Hermans \& T. Gieser (Eds.), Handbook of dialogical self theory (pp. 301-318). Cambridge: Cambridge University Press.

Gregg, Gary S. (2013). Religious Voices and identity in the life-narratives of young adult Morocccans. In M. Buitelaar \& H. Zock (Eds), Religious voices in self-narratives. Making sense of life in times of transition (pp. 83-102). Berlin/Boston: Walter de Gruyter.

Hermans, H.J.M. (2006). Dialoog en misverstand. Leven met de toenemende bevolking van onze innerlijke ruimte [Dialogue and misunderstanding. To live with an increasing population of our inner space]. Soest: Uitgeverij Nelissen.

Hermans, H. J. M., \& Gieser, T. (2012). Handbook of dialogical self theory. Cambridge: Cambridge University Press.

Hermans, H. J. M., \& Hermans-Jansen, E. (1995). Self-narratives: The construction of meaning in psychotherapy. New York: Guildford Press.

Hermans, H. J. M., \& Hermans-Konopka, A. (2010). Dialogical self theory: Positioning and counterpositioning in a globalizing society. Cambridge: Cambridge University Press.

Janssens, M. (2010). Autobiografische reflectie en de transformatie van persoonlijke ervaringen [Autobiographical reflection and the transformation of subjective experiences].Tijdschrift Voor Lerarenopleiders, (VELON/VELOV), 31(4), 13-20.

Kelchtermans, G. (1994). De professionele ontwikkeling van leerkrachten vanuit het biografisch perspectief [Professional development of teachers from a biographic perspective]. Leuven: Universitaire Press ( $\mathrm{PhD}$ thesis).

Kelchtermans, G. (2006). Capturing the multidimensionality of teacher professionalism: Broad and deep reflection. In J. van Swet, P. Ponte, \& B. Smit (Eds.), Postgraduate programs as platform: An interactive and research-led approach (pp. 97-109). Rotterdam: Sense Publishers.

Kelchtermans, G., \& Hamilton, M.L. (2004). The dialects of passion and theory: Exploring the relation between self-study and emotion. In J.J. Loughran, M.L. Hamilton, V. K. LaBoskey \& T.L. (Eds). International handbook of self-study of teaching and teacher education practices (pp. 785-810). Springer International Handbooks of Education series. Dordrecht: Springer.

König, J. (2012). Moving experience, complexities of acculturation. Amsterdam: VU University Press.

Kortam, L. (2004). Multicultureel competent (samen-)leven [Multiculturally competent (co-) existence]. Public Lecture, 19 November. Driebergen: Hogeschool De Horst. 
Maddux, J. E. (2005). Stopping the "madness": Positive psychology and the deconstruction of the illness ideology and the DSM. In C. R. Snyder \& S. J. Lopez (Eds.), Handbook of positive psychology (pp. 13-25). New York: Oxford University Press.

Marcia, J. E. (1980). Identity in adolescence. In J. Adelson (Ed.), Handbook of adolescent psychology (pp. 159-187). New York: Wiley.

Matthys, M. (2010). Doorzetters: een onderzoek naar de betekenis van de arbeidersafkomst voor de levensloop en loopbaan van universitair afgestudeerden [Go getters. An Inquiry into the meaning of a working-class origin for the life course and career of university graduates]. Amsterdam: Amsterdam University Press.

Molenwijk, B., Kleinlugtenbelt, D., \& Widdershoven, G. (2011). The role of emotions in moral case deliberation: Theory, practice and methodology. Bioethics, 25(7), 383-393.

Nguyen, P.-M., Terlouw, C., \& Pilto, A. (2006). Culturally appropriate pedagogy: The case of group learning in a Confucian Heritage Culture context. Intercultural Education, 17(1), 1-19.

Okafor, S., \& Honey, R. (1998). Hometown associations: Indigenous knowledge and development in Nigeria. Sterling, VA: Stylus Publishing.

Pitstra, F. (2013). Religious voices in autobiography and biography: analyzing life stories using elements of the theories of McAdams and Hermans. In M. Buitelaar \& H. Zock (Eds.), Religious voices in self-narratives: Making sense of life in times of transition (pp. 37-52). Berlin/Boston: Walter de Gruyter.

Putnam, R. (2001). Bowling alone: The collapse and revival of American community. New York: Simon and Schuster.

Selan, R. L. (1980). The growth of interpersonal understanding. New York: Academic Press.

Smaling, A. (2009). Generaliseerbaarheid in kwalitatief onderzoek [Generalisability in qualitative research]. Kwalon, 14(3), 5-12.

Stake, R. E. (2005). Qualitative case studies. In N. K. Denzin \& Y. S. Lincoln (Eds.), The Sage handbook of qualitative research (pp. 443-466). Thousands Oaks/London/New Delhi: Sage.

Sundén, H. (1966). Die Religion und die Rollen [Religion and roles]. Berlin: Töpelmann.

Swanborn, P.G. (1994). Methoden van sociaal-wetenschappelijk onderzoek. Nieuwe editie [Methods in social sciences. New edition]. Amsterdam/Meppel: Boom.

Taylor, C. (1991). Sources of the self. The making of modern identity. Cambridge: Cambridge University Press.

Ter Avest (2014a). Af en toe stemmen [Fine tuning and agreeing]. Amsterdam: Science Guide/Gopher B.V.

Ter Avest, I. (2014b). Exclusive inclusion. Special treatment for first-generation students: Presentation at the University of Sivas, Turkey.

Ter Meulen, B. (2016). Bespreek ethische dilemma's in morel beraad [Discuss ethical dilemmas in moral deliberations]. Medisch Contact, 4, 34-37.

Vandamme (2014). De HBO-docent en zijn identiteit. Jezelf Boetseren in je beroepsrol [The university teacher and his identity. To model yourself in your professional role]. Mortsel: Het Ontwikkelingsinstituut bvba.

Verhofstadt-Denève, L. (1995). Zelfreflectie en Persoonsontwikkeling: Een handboek voor ontwikkelingsgerichte psychotherapie [Self-reflection and personal development: A handbook for development-oriented psychotherapy]. Leuven: Uitgeverij Acco.

Verhofstadt-Denève, L. (2012). Psychodrama: From a dialogical self theory to a self in dialogical action. In H. J. M. Hermans \& T. Gieser (Eds.), Handbook of dialogical self theory (pp. 132-150). Cambridge: Cambridge University Press.

Zittoun, T. (2013). Religious traditions as means of innovation: The use of symbolic resources in the life course. In M. Buitelaar \& H. Zock (Eds.), Religious voices in self-narratives: Making sense of life in times of transition (pp. 129-148). Berlin/Boston: Walter de Gruyter.

\section{The author}

Ina ter Avest was educated and trained as a psychologist of culture and religion. In her Ph.D. research, she explored the relation of interreligious education (Christian and Islamic RE) and the religious development of children at the age of 8-12. She was trained as a coach in the Self Confrontation Method and in psychodrama. For many years, Ina ter Avest was professor in "Worldview and Education", at 
Stenden University (Leeuwarden) and at Inholland University (Amsterdam). As a senior lecturer at VU University (Amsterdam), Ina ter Avest participated in the European "Religion in EDucation. A Contribution to dialogue or a factor of conflict in transforming societies of European countries" (REDCo) research project. In her own private practice, Ina ter Avest explores and coaches her clients regarding existential questions. 